\title{
Influence of chlorella on hematological parameters and metabolism of rhesus monkeys
}

\author{
N.V. Gaponov ${ }^{1,2 *}$, O.P. Neverova ${ }^{3}$, O.V. Gorelik ${ }^{3}$, S.Y. Kharlap ${ }^{3}$, and T.I. Bezhinar ${ }^{4}$ \\ ${ }^{1}$ Federal state budgetary institution Research Institute of Medical Primatology, 354376, Mira str., 177, \\ Sochi, Russia \\ ${ }^{2}$ All-Russian Research institute of lupine - branch of the NSC "All-Russian Research Institute of fodder \\ named after V.R. Williams", 241524, Berezovaya str., 2, Michurinsky village, Bryansk district, \\ Bryansk region, Russia \\ ${ }^{3}$ Ural State Agrarian University, 620075, Karl Liebknecht str., 42, Yekaterinburg, Russia \\ ${ }^{4}$ South Ural State Agrarian University, 454080, Lenin Avenue, 76, Chelyabinsk, Russia
}

\begin{abstract}
In our experiment, we studied the possibility of including dry chlorella in primate feeding structures of the diet. In order to replace highnutritional protein feed of plant and animal origin. Along with dry chlorella, the effect of chlorella suspension, as a dietary supplement, on the primate organism has been studied. For experiments with dry chlorella, the primate feeding ration was changed. In the structure of the diet of dry chlorella feeding was subjected to substitution: dry milk by $90 \%$, egg powder by $9 \%$. Whereas chlorella emulsion with a cell density in the culture fluid of 55-60 million / $\mathrm{cm} 3$ rhesus monkeys was obtained with drinking water. At the rate of $2.8 \mathrm{ml} / \mathrm{kg}$ body weight per day and complete feed (CF), as in the control group. The data obtained macaca mulatta of the experiment indicate that the inclusion of chlorella in the structure of rations of primates, both dry and with culture liquid, contributes to a better digestibility of feed nutrients. Significantly increases the level of metabolism in the body of primates of the experimental groups. And the results of hematological studies indicate an increase in the natural resistance of the organism.
\end{abstract}

\section{Introduction}

Out of freshwater algae, the most used one is the single-cell green algae - Chlorella, which proved to be a convenient model for laboratory researches and industrial use. Chlorella is a single - cell green algae; its single-core vegetative cells usually do not exceed 15 microns in diameter, protoplast has one cachoid chloroplast with one pyrenoid in the thickened part [16]. Chlorella is multiplied exclusively by autospores occurring usually by 4-8 per one cell [15]. It is known that chlorella vitamins content surpasses all vegetable feed and crops of agricultural production, it has all the necessary amino acids, including essential ones. On the other hand, these algae can be used in agriculture as fertilizers, as their composition in

\footnotetext{
* Corresponding author: nv.1000@bk.ru
} 
addition to biogenic elements include phytohormones that affect plant development [9]. Yet the data on using algae in soil fertilizers is insufficient. Studies show that there is an increase in biomass, increased fixation of atmospheric nitrogen, oxygen, and decrease in the growth of pathogenic bacteria affecting the development of crop species. Many compounds present in chlorella are accumulated in its cultural medium [11].

At the turn of the last years, the work on the wide production of chlorella in a number of scientifically developed countries has intensified, and this is natural, since physiological and biochemical studies of chlorella testify to its prospects as a producer of valuable organic compounds. Cultivation of microalgae occurs on mineral nutrient media within 10 days [17]. Chlorella is an active producer of proteins, carbohydrates, lipids, vitamins, with easily adjustable ratio of these compounds when changing the conditions of its cultivation. On average, the total nutritional value of dried chlorella is: $45 \%$ protein; $20 \%$ carbohydrates; $20 \%$ fat; $5-10 \%$ fibers with minerals of zinc, iron, magnesium, calcium, phosphorus, etc. Among extracellular products of chlorella metabolism were found vitamin B1 (thiamine), B2 (riboflavin), B3 (pantothenic acid), B5 (nicotinic acid), B6 (pyridoxine), B12 (cyancobalamine), folic acid and its derivatives), para-aminobenzoic acid, N (biotin), inosite. Contents of these vitamins in the culture fluid significantly exceeds their number in cells. Therefore, when using chlorella biomass as a feed additive, it should be taken into account and solder the animal cell suspension without losing vitamins and other biologically active substances in the culture fluid.

Introduction of chlorella suspension into the diet of farm livestock reduces to a minimum the mortality of young animals. Promotes better absorption of feed, improves peristaltic function of the intestine, preventing stagnation and diverticulitis causing inflammation of the mucosa in the digestive tract shells, reabsorption of toxic substances, as well as the distribution of non - saprophytic microbes. The anti-inflammatory and antioxidant properties of chlorella provide removal of symptoms in ulcerative colitis, irritable bowel syndrome and Crohn's disease. It increases the resistance of the body to diseases thanks to the improvement of immunological indicators. In repeated studies with chlorella, the level of gamma interferon showed a significant increase, indicating an improvement in immunity against viral and bacterial infections, which is especially important in the cage keeping of animals in winter and is a preventive remedy against avitaminosis diseases [1].

The antioxidant property of chlorella has been proven in experiments on rats. In particular, it was shown that oxidative stress (lipid peroxidation) in rats with diabetes could be reduced by chlorella. Isolated immune cells (macrophages) were stimulated by bacterial elements (lipopolysaccharides). To protect against pathogens, these cells create nitrogen monooxide (NO), which causes inflammation and oxidative stress. In the treatment of these cells with chlorella dichloromethane extract, NO yield was reduced, and the enzymes that can reduce oxidative stress were significantly more active (superoxide dismutase, catalase, glutathione peroxidase and glutathione reductase) [13].

Due to its high antioxidant activity, chlorella protects cells from free radicals and therefore from DNA damage. Another important action of chlorella is to increase the action of $\mathrm{T}$ cells, which makes the body more able to identify and destroy damaged cells that can otherwise be divided and form tumors. Therefore, chlorella drugs are used after radiation and chemotherapy, which reduces their side effects. Since these procedures destroy the intestinal mucosa and hinder digestion, chlorella provides the body with a stable supply of many essential nutrients $[2,4,12]$. In the diet of humans and animals chlorella can be added in the form of suspension, paste or dry biomass. The most appropriate is the use of suspension, since half of the water-soluble vitamins is in the culture fluid [10].

The chlorophyll molecule is similar in structure to the blood hemoglobin molecule. Scientific research shows that chlorophyll can increase blood hemoglobin levels [18]. 
Taking into account the above, the purpose of the study was to establish the possibility of substitution on chlorella dry high-protein feed of animal origin. To study the effects of chlorella dry and with culture fluid on hematological, biochemical indices of primate blood and determine the coefficients of nutrient digestibility of diets of male rhesus monkeys.

\section{Materials and methods}

In order to achieve the set goals, scientific research was carried out on male rhesus monkeys. For this purpose, the primates were divided into three groups - control and two experimental $[3,5]$.

In the control group, primates consumed complete granular feed and tap water. Complete granular feed for the experiment was produced at the production site of the Federal state budgetary institution "Research Institute of Medical Primatology" [8]. In which $21.4 \%$ of energy nutrient accounted for wheat. The share of soybean cake in the structure of feed accounted for $17.42 \%$. Sunflower cake amounted to $13.83 \%$. A significant part of the diet energy is milk skim powder and it is $14.39 \%$. The diet of the control group is balanced by the introduction of sunflower oil, which amounted to $0.8 \%$. The remaining $32.16 \%$ of energy accounted for corn gluten $11.24 \%$, corn $13.35 \%$, egg powder $3.3 \%$ and sugar $4.27 \%$.

In the second experimental group with drinking water, rhesus monkeys received $2.8 \mathrm{ml} / \mathrm{kg}$ of live weight per day chlorella suspension and complete feed (CF). Chlorella suspension with a concentration of 55-60 million $/ \mathrm{cm} 3$, was purchased from the manufacturer "Biocenter" Geoflora" LLC. Primates of the third experimental group in the structure of the diet, on dry chlorella, partially replaced some feed: milk powder by $90 \%$, egg powder by $9 \%$, and in the diet structure of the 3rd experimental group chlorella was $14 \%$. To carry out experiments dry chlorella was purchased in the company of the manufacturer - "Grin" LLC. The number of animals aged 7-15 years in the experiment was 15, 5 per group respectively. The duration of the experiment is 35 days. The scheme of the experiment is presented in (Table 1).

Table 1. The scheme of the experiments

\begin{tabular}{|c|c|l|}
\hline \multirow{2}{*}{ Groups } & $\begin{array}{c}\text { Q-ty } \\
\text { of animals }\end{array}$ & \multicolumn{1}{|c|}{ Feeding conditions } \\
\cline { 3 - 3 } & 5 & Macaca mulatta aged 7 - 15 years \\
\hline $\begin{array}{c}\text { I } \\
\text { Control }\end{array}$ & 5 & Complete feed $(\mathrm{CF})$ \\
\hline $\begin{array}{c}\text { II } \\
\text { Experimental }\end{array}$ & 5 & CF $-14 \%$ Dry Chlorella suspension $-2.8 \mathrm{ml} / \mathrm{kg} 1 . \mathrm{w}$. \\
\hline $\begin{array}{c}\text { III } \\
\text { Experimental }\end{array}$ & 5 & \\
\hline
\end{tabular}

The material for the study was venous blood, blood serum, feed and stool of primates. Blood was taken from the monkeys before the application of chlorella and 35 days after the completion of the experiment. All blood samples (2.5-3.0 ml) were taken from the elbow or femoral vein of animals on an empty stomach and stabilized with heparin solution. Laboratory tests of animal blood were carried out on automatic hematological analyzer of "Beckman Coulter", USA brand CoulterAcT 5diffCP. In order to study the effect of dietary supplements on hematological parameters, we determined the level of red blood cells, white blood cells, platelets, hemoglobin concentration, hematocrit, average volume of erythrocytes, erythrocyte anizocytosis, erythrocyte sedimentation rate (ESR). The ESR was determined by the method of Panchenkov. 
The blood serum was obtained according to the standard method. Venous blood, without anticoagulants in a centrifuge glass test tube, was kept at room temperature $\left(+15-20^{\circ} \mathrm{C}\right)$ until clot formation. A thin glass stick was moved on the inner walls of the test tube (in a circle) to separate the clot from the walls of the test tube and centrifuged for 10 minutes (1000-1500 g). The resulting serum was poured into disposable plastic tubes with screw-in plugs. The serum without hemolysis was used in the work. Its biochemical analysis (total protein, glucose, total bilirubin, calcium, phosphorus) was carried out in 2-3 hours after taking the sample using standard sets of "High Technology Inc" (USA) on the semi-automatic analyzer BioChem SA (USA).

The balance experiment for determining the digestibility of nutrients of the diet was divided into two periods. Preparatory (5 days). The purpose of which is to exclude the influence of previous feeding and to accustom primates to the conditions of cage keeping. The scientists (experiment of 5 days) during this period carried out careful accounting of consumed feed and produced excrement. The schedule of feeding primates in the experimental period was the same as in the control group.

Stool was collected daily at the same time (morning and evening), weighed and rubbed in mortar. At each collection, 50\% of the homogenized mass was taken for analysis. The collected portions were stored in the refrigerator. After the end of the experimental (accounting) period, the initial moisture was determined in the collected stool by drying at 60-70 0C to a constant mass. The obtained air-dry mass was thoroughly grinded and transferred for the analysis [2].

Experiments on animals were carried out in accordance with the requirements of the order of the Ministry of Health of the Russian Federation No. 267 dated June 19, 2003. "On approval of the rules of laboratory practice", orders of the Ministry of Health of the USSR No. 742 dated November 13, 1984 "On Approval of Rules of Work with Use of Experimental Animals" and No. 48 of January 23, 1985 "On Control of Experimental Animal Works", the ethical standards set out in the Good Laboratory Practice (GLP), the Helsinki Declaration (2000) and the European Community Directives 86/609EEC

The obtained results were processed statistically and expressed in the form of arithmetic averages and their standard errors. The statistical significance of differences was determined by means of one-factor dispersion analysis with subsequent posteriori comparisons using the Dunnett method and the t-criterion of Student. The differences were considered valid at the level of statistical significance $\mathrm{p}<0.05$.

\section{Discussion and results}

Blood changes are the first sign of any changes occurring in the body as a whole. Therefore ,the blood test in the formulation of experiments has a great diagnostic value (Table 2).

One of the important indicators of the form elements of blood for the diagnosis of the state of the body is red blood cells. In the body, they perform transport function for the transport of oxygen and carbon dioxide. In the blood test at the beginning of the experiment, it was found that the number of erythrocytes in the control group and the second experimental group slightly exceeded the indices of the upper bounds of the reference values by $1.6 \%$ and $1.7 \%$ respectively. This can be caused by a significant increase in ambient temperature by the time the experience begins. At the end of the experiment, after the application of chlorella suspension in the second experimental group, there is a recovery of erythrocyte indices to the physiological norm of content with accuracy $(p<0.05)$. In the third experimental group, the amount of red blood cells at the beginning of the experiment and after the application of dry chlorella in the structure of rations did not change. The main function of erythrocytes is inextricably linked to the properties of the hemoglobin protein contained therein. At the 
beginning of the experiment, the level of hemoglobin was within the physiological norm. At the end of the experiment, after the application of chlorella, the hemoglobin indices were at the level of mean reference values.

Table 2. Hematological parameters of rhesus monkeys $(\mathrm{X} \pm \mathrm{Sx})$

\begin{tabular}{|c|c|c|c|c|c|c|c|c|c|c|}
\hline \multirow[t]{2}{*}{ Group } & $\begin{array}{c}\text { Leukocytes } \\
\text { (WBC), } \\
\text { x } 10^{9} / 1\end{array}$ & $\begin{array}{c}\text { Erythrocytes } \\
\text { (RBC), } \\
\times 10^{12} / 1\end{array}$ & $\begin{array}{c}\text { Hemoglobin } \\
\text { (HGB), } \\
\mathrm{g} / 1\end{array}$ & $\begin{array}{c}\text { Hematocrit } \\
\text { (HCT) } \\
1 / 1\end{array}$ & \begin{tabular}{|c} 
Mean \\
corpuscula \\
r volume \\
$(\mathrm{MCV})$ \\
$\mathrm{x} 10^{-15} 1$
\end{tabular} & $\begin{array}{c}\text { Mean } \mathrm{Hb} \\
\text { content in } \\
\text { red blood } \\
\text { cells } \\
(\mathrm{MCH})\end{array}$ & $\begin{array}{c}\text { Red cell } \\
\text { distribution } \\
\text { width } \\
\text { (RDW), \% }\end{array}$ & $\begin{array}{c}\text { Platelets } \\
\text { (PLT), } \\
\times 10^{9} / 1\end{array}$ & $\begin{array}{c}\text { Red cell } \\
\text { distribution } \\
\text { width (MPV) }\end{array}$ & $\begin{array}{l}\mathrm{ESR}, \\
\mathrm{mm} / \mathrm{h}\end{array}$ \\
\hline & $5.5-13$ & $5-6.2$ & $110-145$ & $0.26-0.45$ & $52-97$ & $18-33$ & $11-16$ & $200-400$ & $6-10$ & $0.5-5$ \\
\hline \multicolumn{11}{|c|}{ At the beginning of the experiment } \\
\hline Control & $\begin{array}{c}9.82 \\
\pm 1.65\end{array}$ & $\begin{array}{c}6.30 \\
\pm 0.05\end{array}$ & $\begin{array}{c}143.40 \\
\pm 1.40\end{array}$ & $\begin{array}{c}0.43 \\
\pm 0.01\end{array}$ & $\begin{array}{l}67.80 \\
\pm 0.42\end{array}$ & $\begin{array}{l}22.76 \\
\pm 0.29\end{array}$ & $\begin{array}{l}12.98 \\
\pm 0.20\end{array}$ & \begin{tabular}{|l|}
308.40 \\
\pm 18.15 \\
\end{tabular} & $\begin{array}{c}9.74 \\
\pm 0.19\end{array}$ & $\begin{array}{c}0.89 \\
\pm 0.10\end{array}$ \\
\hline \begin{tabular}{|c|} 
2nd \\
experiment
\end{tabular} & $\begin{array}{l}12.60 \\
\pm 0.99 \\
\end{array}$ & $\begin{array}{c}6.31 \\
\pm 0.18 \\
\end{array}$ & $\begin{array}{c}144.80 \\
\pm 6.14 \\
\end{array}$ & $\begin{array}{c}0.43 \\
\pm 0.02 \\
\end{array}$ & $\begin{array}{l}68.40 \\
\pm 1.10 \\
\end{array}$ & $\begin{array}{l}22.92 \\
\pm 0.46 \\
\end{array}$ & $\begin{array}{l}13.26 \\
\pm 0.35 \\
\end{array}$ & \begin{tabular}{|l|}
417.60 \\
\pm 23.22 \\
\end{tabular} & $\begin{array}{c}9.04 \\
\pm 0.40 \\
\end{array}$ & $\begin{array}{c}1.10 \\
\pm 0.11 \\
\end{array}$ \\
\hline \begin{tabular}{|c|} 
3rd \\
experiment
\end{tabular} & $\begin{array}{l}11.48 \\
\pm 1.55 \\
\end{array}$ & $\begin{array}{c}6.14 \\
\pm 0.39 \\
\end{array}$ & $\begin{array}{c}135.20 \\
\pm 9.20 \\
\end{array}$ & $\begin{array}{c}0.41 \\
\pm 0.03 \\
\end{array}$ & $\begin{array}{l}66.00 \\
\pm 0.79 \\
\end{array}$ & $\begin{array}{l}21.98 \\
\pm 0.36 \\
\end{array}$ & $\begin{array}{l}13.40 \\
\pm 0.29 \\
\end{array}$ & \begin{tabular}{|l|}
291.60 \\
\pm 47.81 \\
\end{tabular} & $\begin{array}{c}9.46 \\
\pm 0.41 \\
\end{array}$ & $\begin{array}{c}0.80 \\
\pm 0.14 \\
\end{array}$ \\
\hline \multicolumn{11}{|c|}{ At the end of the experiment } \\
\hline Control & $\begin{array}{l}10.82 \\
\pm 1.99 \\
\end{array}$ & $\begin{array}{c}6.43 \\
\pm 0.17 \\
\end{array}$ & $\begin{array}{c}145.00 \\
\pm 0.50\end{array}$ & $\begin{array}{c}0.43 \\
\pm 0.00\end{array}$ & $\begin{array}{l}68.20 \\
\pm 0.42 \\
\end{array}$ & $\begin{array}{l}22.84 \\
\pm 0.30\end{array}$ & $\begin{array}{l}13.22 \\
\pm 0.29\end{array}$ & \begin{tabular}{|l|}
316.00 \\
\pm 25.62 \\
\end{tabular} & $\begin{array}{c}9.94 \\
\pm 0.33 \\
\end{array}$ & $\begin{array}{c}0.91 \\
\pm 0.12\end{array}$ \\
\hline \begin{tabular}{|c|}
$\begin{array}{c}2 \mathrm{nd} \\
\text { experiment }\end{array}$ \\
\end{tabular} & $\begin{array}{l}13.38 \\
\pm 1.83 \\
\end{array}$ & $\begin{array}{l}5.84 * \\
\pm 0.09 \\
\end{array}$ & $\begin{array}{c}137.40 \\
\pm 3.82 \\
\end{array}$ & $\begin{array}{c}0.41 \\
\pm 0.01 \\
\end{array}$ & $\begin{array}{l}69.80 \\
\pm 0.96 \\
\end{array}$ & $\begin{array}{l}23.46 \\
\pm 0.41 \\
\end{array}$ & $\begin{array}{l}13.14 \\
\pm 0.39 \\
\end{array}$ & \begin{tabular}{|l|}
365.60 \\
\pm 59.72 \\
\end{tabular} & $\begin{array}{c}9.76 \\
\pm 0.34 \\
\end{array}$ & $\begin{array}{c}1.50 \\
\pm 0.25^{*} \\
\end{array}$ \\
\hline \begin{tabular}{|c|} 
3rd \\
experiment
\end{tabular} & $\begin{array}{l}10.22 \\
\pm 1.37 \\
\end{array}$ & $\begin{array}{c}6.14 \\
\pm 0.19 \\
\end{array}$ & $136.80 \pm 3.68$ & $\begin{array}{c}0.41 \\
\pm 0.01 \\
\end{array}$ & $\begin{array}{c}67.20 \\
\pm 0.82 * * \\
\end{array}$ & $\begin{array}{l}22.28 \\
\pm 0.35\end{array}$ & $\begin{array}{l}13.64 \\
\pm 0.31 \\
\end{array}$ & \begin{tabular}{|l|}
273.00 \\
\pm 27.05 \\
\end{tabular} & $\begin{array}{c}9.96 \\
\pm 0.49 \\
\end{array}$ & $\begin{array}{c}1.10 \\
\pm 0.41\end{array}$ \\
\hline
\end{tabular}

The level of leukocytes in the blood is of great importance, their concentration directly affects the overall functioning of the immune system. In our experiment, the leukocyte levels was within normal limits. Yet, at the end of the experiment there is a slight increase in the second experimental group of $2.9 \%$ relative to the upper limit of the reference values.

The percentage ratio of the blood volume to the volume occupied by red blood cells (Hematocrit) and ESR, both at the beginning of the experiment and after the application of chlorella, are within the limits of physiological norm.

Platelets, as form elements of blood, participate in the provision of hemostasis. In our experiment, at the time of the beginning of the experiment, the number of platelets in primates of the control group was within the reference values of 200 to 400 billion. /l. But in the second experimental group there is a slight increase in platelet content by $4.4 \%$, which may be due to insufficient iron content in diets. Results of blood tests at the end of the experiment showed that in experimental groups, as a result of the use of chlorella, the number of platelets stabilized to physiological norm.

Thus, in our experiment in the study of form elements of blood, as a result of chlorella application in the form of suspension and dry in the composition of granular feed, no critical increase or decrease in hematological indices relative to the reference values was revealed. Therefore, the use of chlorella in feeding primates has a positive effect on the condition of 
their body. Has some positive effect on the blood picture, expressed by more favorable changes in hematological parameters.

For in-depth control over the complete feeding of primates, especially when using dry chlorella in full feed, and to ensure prompt response to nutritional imbalances and adjustment of diets, the biochemical indicators of blood serum were determined. For more complete display of metabolism in blood serum the following were determined: protein, glucose, calcium, phosphorus, bilirubin (Table 3) [3].

Table 3. Biochemical indicators of blood serum $(\mathrm{X} \pm \mathrm{Sx})$

\begin{tabular}{|l|c|c|c|c|c|}
\hline \multicolumn{1}{|c|}{ Groups } & $\begin{array}{c}\text { Glucose } \\
(\mathrm{mmol} / \mathrm{L})\end{array}$ & $\begin{array}{c}\text { Bilinubin } \\
(\mathrm{umol} / \mathrm{L})\end{array}$ & $\begin{array}{c}\text { Phosphorus } \\
(\mathrm{mmol} / \mathrm{L})\end{array}$ & $\begin{array}{c}\text { Calcium } \\
(\mathrm{mmol} / \mathrm{L})\end{array}$ & $\begin{array}{c}\text { Protein } \\
(\mathrm{g} / \mathrm{l})\end{array}$ \\
\hline \multicolumn{7}{|c|}{ At the beginning of the experiment } \\
\hline 1st control & $4.43 \pm 0.44$ & $6.99 \pm 2.74$ & $1.17 \pm 0.19$ & $2.56 \pm 0.06$ & $89.31 \pm 8.40$ \\
\hline 2nd experimental & $5.46 \pm 0.78$ & $8.93 \pm 2.77$ & $0.88 \pm 0.18$ & $2.47 \pm 0.06$ & $85.63 \pm 3.32$ \\
\hline 3rd experimental & $4.59 \pm 0.46$ & $6.87 \pm 5.11$ & $1.33 \pm 0.17$ & $2.65 \pm 0.11$ & $103.97 \pm 2.55$ \\
\hline \multicolumn{7}{|c|}{ At the end of the experiment } \\
\hline 1st control & $3.32 \pm 0.38$ & $6.98 \pm 1.47$ & $0.61 \pm 0.12$ & $2.01 \pm 0.17$ & $80.12 \pm 1.66$ \\
\hline 2nd experimental & $3.68 \pm 0.33$ & $4.16 \pm 0.66^{*}$ & $0.44 \pm 0.14$ & $2.04 \pm 0.10$ & $81.87 \pm 4.91^{*}$ \\
\hline 3rd experimental & $6.73 \pm 0.51$ & $10.38 \pm 5.28$ & $0.77 \pm 0.17$ & $2.75 \pm 0.12$ & $89.15 \pm 3.48$ \\
\hline
\end{tabular}

Blood glucose levels were determined to assess the functions of the endocrine system and monitor the state of carbohydrate metabolism of primates. At the beginning of the experiment, the glucose level was within the physiological norm. But at the end of the experiment, in the third experimental group after the application of dry chlorella in the structure of rations, the glucose level increased and approached the upper values of the physiological norm.

Bilirubin is a bile pigment that appears from hemoglobin as a result of erythrocyte decay in liver cells. At the beginning of the experiment, bilirubin level is within normal limits. At the end of the experiment the level of bilirubin in the third experimental group is much higher, relative to the control by $48 \%$, but at the same time it is within the limits of the physiological norm.

At the beginning of the experiment, the level of calcium and phosphorus in the blood of the experimental group was within the reference values. By the end of the experiment, the indicators in the experimental groups and the control group decreased.

Analysis of protein metabolism showed that at the beginning of the experiment in the third experimental group there was a significant increase relative to the norm, but at the end of the experiment, after application of dry Chlorella in the structure of rations, the total protein in the blood serum returned to the physiological norm. At the same time, relative to the control group there is an increase of $11 \%$, and in the second group by $2.1 \%$, respectively, which indicates a positive effect of chlorella on the body of primates. 
Daily accounting of feed eaten by animals and conducted analysis of its chemical composition allowed to establish the amount of nutrients consumed per day. And the accounting of stool and its chemical composition allowed to determine the amount of digested nutrients (Table 4).

Table 4. Nutrient digestibility, $\%(\mathrm{X} \pm \mathrm{Sx})$

\begin{tabular}{|l|c|c|c|c|c|c|c|}
\hline & & & & & & \\
Indicators, \% & $\begin{array}{c}\text { Crude } \\
\text { protein }\end{array}$ & Crude fat & Crude fiber & Crude ash & $\begin{array}{c}\text { Crude } \\
\text { NFES }\end{array}$ & Calcium & $\begin{array}{c}\text { Phosphor } \\
\text { us }\end{array}$ \\
& & & & & & & \\
\hline Control & $65.34 \pm$ & $38.09 \pm$ & $25.88 \pm$ & $41.58 \pm$ & $78.05 \pm$ & $44.37 \pm$ & $59.79 \pm$ \\
& 1.04 & 0.98 & 1.01 & 0.88 & 1.12 & 1.94 & 2.01 \\
\hline 2nd & $69.52 \pm$ & $42.79 \pm$ & $30.02 \pm$ & $53.90 \pm$ & $79.90 \pm$ & $53.66 \pm$ & $60.51 \pm$ \\
experimental & 0.95 & 0.79 & 0.90 & 1.00 & 2.03 & $1.58^{*}$ & 1.61 \\
\hline 3rd & $72.17 \pm$ & $40.70 \pm$ & $30.66 \pm$ & $60.51 \pm$ & $82.20 \pm$ & $58.17 \pm$ & $67.86 \pm$ \\
experimental & $0.96^{* *}$ & 0.87 & 1.12 & 1.21 & 2.03 & 1.96 & 3.12 \\
\hline
\end{tabular}

Analysis of physiological experiments results showed that the coefficients of nutrient digestibility of the studied feeding diets with dry chlorella and suspension in primates of experimental groups were significantly higher than in the control group. Thus, the digestibility of crude protein in the second experimental group was higher by $6.39 \%$, in the third experimental group by $10.45 \%$ with accuracy $(p<0.01)$. The digestibility of crude fat was the highest in the second experimental group and compared to the control group was higher by $12.33 \%$; in the third experimental group, the digestibility of crude fat was higher than in the control group by $6.85 \%$. Positive dynamics of crude calcium fiber and phosphorus digestibility in experimental groups was noted, it was higher than in the control one. Crude ash was better digested in the third experimental group by $45.5 \%$, in the second $-29.6 \%$. Crude NFES was better digested by primates of the third experimental group by $5.31 \%$. A similar pattern is observed in phosphorus. Primates of the third experimental group better digested phosphorus by $13.5 \%$, and primates of the second experimental group by $1.2 \%$.

\section{Conclusion}

Thus, the use of dry chlorella in the structures of primate rations as a substitute for highprotein feed of plant and animal origin, had a positive effect on digestibility of nutrients. On the basis of hematological studies, the beneficial effect of chlorella on the body of primates and stimulation of protein metabolism is proved. Preparation of complete granular feed with the use of chlorella gives an opportunity to balance the diet for most nutrients and biologically active substances. Similar patterns characterize the use of chlorella suspension, as a result of experiments with which the best digestibility indicators were noted, indicating that the use of chlorella suspension allows to significantly increase the level of metabolism. This, in turn, affected the level of nutrient use of the diet and allowed to stimulate the organism resistance of the experimental group of primates.

\section{References}

1. N.I. Bogdanov, Chlorella suspension in diet of farm animals (Penza, 2006)

2. N.V. Gaponov, Y.P. Chuguev, I.I. Chugueva, Veterinary medicine 1, $43-(2020)$ 
3. N.V. Gaponov, Bulletin of Krasnoyarsk State Agrarian University 7, 96-102 (2019)

4. N.V. Gaponov, S.V. Svistunov, Collection of scientific works of the Krasnodar scientific center on animal science and veterinary medicine, , 8(1), 188-193 (2019)

5. N.V. Gaponov, Combined feed, 6, 40-42 (2019)

6. M.I. Davydov, V.A. Normantovich, New approaches in combined treatment of cancer, 224 (Medicine, M., 2016)

7. A.P. Kalashnikov, V.I. Fisinin, V.V. Shcheglov et al, Norms and rations of feeding farm livestock. Reference manual, 456, (Moscow, 2003)

8. A. Kozhanova, Plant reaction to application of chlorella vulgaris suspension as biofertilizer, Scientific Community of Students of the XXI Century. Natural Sciences: collected works XIII Intern, 13 (2013)

9. O. E. Molchanov, D.G. Prokhorov, Proper nutrition in oncological diseases, 288 (Dilya - M., 2015)

10. A.I. Ovsyannikov, Fundamentals of experimental business in animal husbandry, 304 (M.: Kolos, 1967)

11. E.M. Suliga, Phytoplankton of small reservoirs in an urbanized environment, Social and ecological problems of small town: All-Russian scientific conference, 185-188 (Balashov, 2008)

12. E.V. Shatskikh, S.S. Gafarov, G.G. Boyarintseva, S.L. Safronov, The use offeed additives in animal husbandry, 102 (Publishing house Yekaterinburg, Ural State Agrarian Academy, 2006)

13. B. Jensen, The Healing Power of Chlorophyll, Jensen's Health and Nutrition, 154 (1973)

14. Murray W. Nabors, Introduction to Botany (San Francisco, CA: Pearson Education, Inc., 2000)

15. S. Nakano et al., Chemosphere, 61 (9), 1244 - 55 (2005)

16. D. Dvoretsky et al. Chemical Engineering Transactions, 361 - 366, 43, (2015)

17. L.W. Parfrey, E. Barbero, E. Lasser, M. Duthorn, D. Bhattacharya, D.J. Patterson, L.A. Katz, PLoS Genet., 2 (12), e220 (2006)

18. H. Takekoshi et al., Oncol. Rep., 14 (2), 409 - 14 (2005) 